\title{
PENGARUH PEMBERIAN MADU ASLI HUTAN SIJUNJUNG TERHADAP TNF a DAN PENYEMBUHAN LUKA PADA TIKUS GALUR WISTAR JANTAN
}

\author{
Reni Puspita ${ }^{1}$, Fadil Oenzil ${ }^{2}$, Desmiwarti ${ }^{3}$
}

\begin{abstract}
Abstrak
Madu memiliki kandungan zat antibakteri, anti inflamasi dan anti oksidan. Penelitian ini bertujuan untuk membuktikan pengaruh pemberian madu untuk menurunkan kadar TNF $\alpha$ dan penyembuhan luka pada tikus galur wistar jantan. Jenis penelitian ini adalah Post Test Only Group Control Design dengan menggunakan 24 ekor tikus galur wistar jantan yang berumur 2-3 bulan, yang terbagi dalam 6 kelompok dan masing - masing kelompok terdapat 4 ekor tikus. Kelompok KN tidak diberikan madu dan povidone iodine, kelompok KP diberikan povidone iodine $10 \%$, kelompok P1 diberi madu dengan konsentrasi 20\%,kelompok P2 diberi madu dengan konsentrasi 40\%, kelompok P3 diberi madu dengan konsentrasi $80 \%$, kelompok P4 diberi madu dengan konsentrasi $100 \%$. Setelah diberi perlakuan selama 10 hari, darah diambil dan diperiksa kadar TNF a dengan mengggunakan metode ELISA. Selain itu juga dilakukan pengukuran terhadap panjang dan lebar luka. Hasil penelitian menunjukkan bahwa rata - rata TNF a kelompok KN 32,25 pg/ml, kelompok KP 39,12 pg/ml, kelompok P1 25,25 pg/ml, kelompok P2 21,92 pg/ml, kelompok P3 $32,03 \mathrm{pg} / \mathrm{ml}$, kelompok P4 27,28pg/ml. Untuk persentase penyembuhan panjang luka didapatkan kelompok $\mathrm{KN}$ 29,17\%, kelompok KP 71,10\%, kelompok P1 49,29\%, kelompok P2 75,68\%, kelompok P3 71,74\%, kelompok P4 $94,22 \%$. Untuk persentase penyembuhan lebar luka didapatkan kelompok KN 30,95\%, kelompok KP 76,60\%, kelompok P1 44,66\%, kelompok P2 83,37\%, kelompok P3 71,18\%, kelompok P4 97,15\%. Pada analisa data didapatkan kadar TNF $\alpha p>0,05$ yang tidak bermakna secara statistik, untuk persentase penyembuhan panjang luka didapatkan $p<0,05$ yang bermakna secara statistik, dan untuk persentase penyembuhan lebar luka didapatkan $p$ $<0,05$ yang bermakna secara statistik. Dapat disimpulkan ada pengaruh pemberian madu terhadap penurunan TNF $\alpha$ dan ada pengaruh pemberian madu terhadap penyembuhan panjang dan lebar luka pada tikus galur wistar jantan.
\end{abstract}

Kata Kunci : Madu, TNF a, Penyembuhan Luka

\begin{abstract}
Honey contains antibacterial, anti-inflammatory and anti-oxidant substances. This study aims to prove the effect of giving honey to reduce TNF a levels and wound healing in male wistar rats. This type of research was the Post Test Only Group Control Design using 24 male wistar rats aged 2-3 months, which were divided into 6 groups and each group contained 4 rats. KN group was not given honey and povidone iodine, KP group was given povidone iodine $10 \%$, group $P 1$ was given honey with a concentration of $20 \%$, group $P 2$ was given honey with a concentration of $40 \%$, group P3 was given honey with a concentration of $80 \%$, group P4 was given honey with concentration $100 \%$. After being treated for 10 days, blood was collected and examined for TNF a levels using the ELISA method. In addition, measurements were also made of the length and width of the wound. The results showed that the average TNF a group KN $32.25 \mathrm{pg} / \mathrm{ml}$, group KP $39.12 \mathrm{pg} / \mathrm{ml}$, group P1 $25.25 \mathrm{pg} / \mathrm{ml}$, group P2 $21.92 \mathrm{pg} / \mathrm{ml}$, group P3 $32.03 \mathrm{pg} / \mathrm{ml}$, P4 group $27.28 \mathrm{pg} / \mathrm{ml}$. For the percentage of wound healing length, KN group $29.17 \%$, KP group $71.10 \%$, group $P 149.29 \%$, group $P 275.68 \%$, group $P 371.74 \%$, group $P 494.22 \%$. For the percentage of wound healing width, the group $K N 30,95 \%$, KP group $76,60 \%$, group $P 144,66 \%$, group $P 283,37 \%$, group $P 371,18 \%$, group $P 497,15 \%$. In the data analysis, it was found that TNF a level $p>0.05$ which was not statistically significant, for the percentage of wound healing length was $p<0.05$ which was statistically significant, and for the percentage of wound healing width was $p<0.05$ which was statistically significant. It can be concluded that there is an effect of giving honey to TNF $\alpha$ reduction and there is an effect of giving honey to healing length and width of wounds in male wistar rats.
\end{abstract}

Keywords: Honey, TNF $\alpha$, wound healing

Affiliasi penulis :1. Program Studi Magister S2 Biomedik FK UNAND, 2. Bagian Biokimia FK UNAND, 3. Bagian Obstetri Gynekologi RSUP M. Jamil Padang

Korespondensi :Reni Puspita

email: preni188@gmail.com, Telp: 085263739455

\section{PENDAHULUAN}

Luka merupakan suatu keadaan kerusakan integritas kulit yang terjadi ketika kulit terkena suhu, $\mathrm{pH}$, zat kimia, gesekan, trauma, tekanan serta radiasi. ${ }^{1}$ Dalam perawatan luka diperlukancara untuk meningkatkan penyembuhan ,mencegah kerusakan kulit lebih lanjut, mengurangi risiko infeksi, dan meningkatkan kenyamanan pasien. Berbagai jenis luka yang dikaitkan dengan tahapan penyembuhan luka memerlukan manajemen luka yang tepat. Perawatan luka saat ini sudah berkembang sangat pesat. Pada perkembangannya, hasil penelitian perawatan luka menunjukkan bahwa lingkungan yang lembab lebih baik dari pada lingkungan yang kering. ${ }^{2}$ TNF- $\alpha$ adalah merupakan salah satu faktor pertumbuhan yang disekresikan dari makrofag, yang dikombinasikan dengan faktor pertumbuhan lainnya, PDGF atau IL-1 $\beta$ meningkatkan dan menghambat produksi kolagen masing-masing, proliferasi fibroblas. ${ }^{3}$ Madu merupakan cairankental seperti sirup yang bewarna cokelat kuning muda sampai coklat 
kemerahan yang dikumpulkan oleh indung madu oleh lebah Apis Mellifera. ${ }^{4}$ Adapun khasiat madu dalam hal mempercepat penyembuhan luka yang disebabkan oleh aliran osmotik, dan efek bioaktif madu. Enzim yang dihasilkan seperti glukosa oksidase memberikan glukosa pada leukosit untuk meningkatkan aktivitas antibakteri. Dalam penelitian menunjukkan bahwa proliferasi limfosit B dan limfosit $\mathrm{T}$ dalam kultur sel dirangsang oleh madu pada konsentrasi serendah $0,1 \%$ dan fagosit juga diaktifkan pada konsentrasi $0,1 \%$. Selain itu madu juga meningkatkan TNF $\alpha, I L 1$, dan pelepasan IL6 yang mengaktifkan respon terhadap infeksi. 5

Berdasarkan latar belakang diatas, maka peneliti ingin mengetahui pengaruh pemberian madu asli hutan Sijunjung terhadap TNF a dan penyembuhan luka pada tikus galur wistar jantan.

\section{METODE}

Penelitian ini dilakukan Laboratorium Farmasi dan Laboratorium Biomedik Fakultas Kedokteran Universitas Andalas selama kurang lebih 3 bulan. Penelitian ini merupakan penelitian eksperimen dengan desain Post-Test Only Control Group Design. Populasi pada penelitian ini adalah tikus galur Wistar, sampel yang digunakan adalah tikus jantan yang memiliki kriteria inklusi, tikus berjenis kelamin jantan, memiliki berat badan 200-300 gram. Jumlah sampel adalah 24 ekor tikus. Sampel dibagi menjadi 6 kelompok. Kelompok KN tidak diberi madu dan povidone iodine, kelompok KP diberi povidone iodine $10 \%$, kelompok $\mathrm{P} 1$ diberi madu dengan konsentarsi $20 \%$, kelompok P2 diberi madu dengan konsentrasi $40 \%$, kelompok P3 diberi madu dengan konsentrasi $80 \%$, dan kelompok P4 diberi madu $100 \%$. Perlakuan diberikan selama 10 hari dan pada hari ke 10 dilakukan pengambilan darah pada tikus. Tikus ditimbang bertanya kemudian dilakukan anestesi dengan menggunakan ether secara inhalasi. Darah tikus diambil melalui sinus obital dan masukkan darah dalam vacutainer sebanyak $5 \mathrm{cc}$. Lakukan centrifuse 4000rpm selama 20 menit, kemudian serum disedot 3cc dan dimasukkan dalam microtube dan bekukan dengan suhu $37^{\circ} \mathrm{C}$. Langkah berikutnya dilakukan pemeriksaan TNF $\alpha$ yang diukur dengan menggunakan metode ELISA (Enzyme-Linked Immunosorbent Assay)

Pemeriksaan TNF a menggunakan metode ELISA, dilakukan di laboratorium Biomedik FK UNAND. Penelitian ini telah mendapatkan persetujuan etik dari Panitia Etik Penelitian di Fakultas Kedokteran Universitas Andalas. Data TNF $\alpha$ dan persentase penyembuhan panjang dan lebar lukayang diperoleh dianalisis dengan uji Kruskal Wallis.

Tabel 1. menunjukkan bahwa TNF $\alpha$ pada kelompok kontrol dan perlakuan tidak terdapat perbedaan yang bermakna $(p>0,05)$, dimana nilai $p=$ 0,455 .

Tabel 2 menunjukkan bahwa terjadi peningkatan persentase penyembuhan panjang luka dan terdapat perbedaan yang bermakna $(p<0,05)$, dimana nilai $p=0,019$

Tabel 1. Nilai Rata-rata Kadar TNF a

\begin{tabular}{lcc}
\hline Kelompok & $\begin{array}{c}\text { TNF } \boldsymbol{\alpha}(\mathbf{p g} / \mathbf{m l}) \\
\text { Mean } \pm \text { SD }\end{array}$ & $\boldsymbol{p}$ \\
\hline KN & $32,25 \pm 13,75$ & \\
KP & $39,12 \pm 16,72$ & 0,455 \\
P1 & $25,24 \pm 9,05$ & \\
P2 & $21,92 \pm 2,91$ & \\
P3 & $32,03 \pm 8,28$ & \\
P4 & $27,28 \pm 2,26$ & \\
\hline
\end{tabular}

*Nilai $p$ didapat dari uji Kruskal Wallis

Tabel 2. Nilai Rata-rata Persentase Penyembuhan Panjang Luka

\begin{tabular}{lcc}
\hline Kelompok & $\begin{array}{c}\text { Penyembuhan Panjang } \\
\text { Luka (\%) } \\
\text { Mean } \pm \text { SD }\end{array}$ & $\boldsymbol{p}$ \\
\hline KN & $29,17 \pm 15,80$ & \\
KP & $71,10 \pm 13,15$ & 0,019 \\
P1 & $49,29 \pm 21,99$ & \\
P2 & $75,68 \pm 27,00$ & \\
P3 & $71,74 \pm 17,39$ & \\
P4 & $94,22 \pm 11,55$ & \\
\hline
\end{tabular}

${ }^{*}$ Nilai $p$ didapat dari uji Kruskall Wallis

Tabel 3. Nilai Rata - rata Persentase Penyembuhan Lebar Luka

\begin{tabular}{ccc}
\hline Kelompok & $\begin{array}{c}\text { Penyembuhan Lebar } \\
\text { Luka (\%) } \\
\text { Mean } \pm \text { SD }\end{array}$ & $\boldsymbol{p}$ \\
\hline KN & $30,95 \pm 24,34$ & \\
KP & $76,60 \pm 2,81$ & \\
P1 & $44,66 \pm 23,27$ & 0,009 \\
P2 & $83,37 \pm 15,68$ & \\
P3 & $71,18 \pm 12,77$ & \\
P4 & $97,15 \pm 5,70$ & \\
\hline
\end{tabular}

Tabel 3 menunjukkan bahwa terjadi peningktan persentase penyembuhan lebar luka dan terdapat perbedaan yang bermakna $(p<0,05)$, dimana nilai $p$ $=0,009$

\section{PEMBAHASAN}

\section{Pengaruh Pemberian Madu terhadap TNF a}

Berdasarkan uji Kruskal Wallis didapatkan bahwa $p>0,05$ dengan nilai $p$ yaitu 0,455 yang berarti pemberian madu berpengaruh terhadap penurunan TNF a walaupun tidak bermakna secara statistik.

Proses penyembuhan luka memerlukan peranan dari mediator pro-inflamasi seperti TNF a dan Interleukin-1. TNF a merupakan mediator pro-inflamasi yang diproduksi oleh makrofag yang berfungsi untuk merangsang sel inflamasi, fibroblas dan sel epitel. Semakin tinggi kadar TNF a pada luka, menandakan proses inflamasi yang sedang berlangsung. ${ }^{6}$

Hasil penelitian ini tidak sesuai dengan penelitian yang disimpulkan oleh Tonks AJ (2003) yang menemukan terdapatnya peningkatan pelepasan TNF a yang memuncak pada 4-6 jam pada monosit darah manusia yang terisolasi setelah distimulasi madu dan Tonks A (2001) yang menemukan peningkatan pelepasan sitokin pro-inflamasi yang potensial (TNF $\alpha$ ) setelah diberikan berbagai madu pada culture sel MonoMac-6 (MM6, sel monosit dan prekursor makrofag) setelah 2 jam. ${ }^{7,8}$

Tidak terdapat kesesuaian antara teori dengan hasil yang didapatkan pada penelitian ini serta dengan penelitian-penelitian sebelumnya kemungkinan dikarenakan oleh waktu pemeriksaan kadar TNF $\alpha$. 
Pada penelitian sebelumnya kadar TNF a akan mencapai puncak 2 sampai 6 jam setelah pemberian madu, sementara pada penelitian ini pemeriksaan kadar TNF $\alpha$ dilakukan 10 hari setelah tikus dilukai dan diberikan madu.

\section{Pengaruh Pemberian Madu terhadap Penyembuhan Luka}

Berdasarkan uji Kruskal Wallis didapatkan bahwa $p<0,05$ dengan nilai $p$ yaitu 0,019 yang berarti terdapat pengaruh pemberian madu terhadap peningkatan persentase penyembuhan panjang luka. Sedangkan untuk penyembuhan lebar lebar didapatkan nilai $p<0,05$ dengan nilai $p$ yaitu 0,009 yang berarti terdapat pengaruh pemberian madu terhadap peningkatan persentase penyembuhan lebar luka.

Pada penelitian ini didapatkan hasil ada pengaruh pemberian madu terhadap proses penyembuhan luka baik proses penyembuhan panjang luka maupun lebar luka. Hasil penelitian ini sesuai dengan yang ditemukan oleh Gethin et al (2008) yang menyimpulkan adanya penurunan ukuran luka setelah menggunakan madu. ${ }^{9}$

Anti bakteri madu telah dipercaya bisa digunakan dalam proses penyembuhan luka. ${ }^{10}$ Berbagai mekanisme telah diterangkan untuk efek anti bakteri madu. Kandungan gula yang tinggi pada madu mampu untuk menghambat pertumbuhan mikroba. Hal ini diyakini sebagai akibat dari efek osmotiknya, yang mencegah pertumbuhan bakteri sehingga mempercepat penyembuhan luka, kandungan gizi dan antioksidan, serta stimulasi kekebalan tubuh, dan senyawa tak dikenal lainnya. ${ }^{11}$ Kandungan gula yang tinggi pada madu tidak satu-satunya alasan untuk efek ini. Jika madu diencerkan dengan air untuk mengurangi kadar gula dan efek osmotiknya, hal itu masih bisa menghambat pertumbuhan bakteri yang menyebabkan infeksi luka. ${ }^{12}$

Hasil penelitian ini juga senada dengan yang ditemukan Molan (1998) yang membuktikan periode penyembuhan yang jauh lebih singkat saat membalut luka dengan pembalut dibandingkan pembalut lainnya. Hal ini juga memperhatikan bahwa menggunakan madu untuk membalut luka yang terinfeksi akan membuatnya menjadi lebih bersih, yang merupakan dasar pertumbuhan jaringan. ${ }^{13}$ Adapun pada pasien yang menderita luka ganas, perbaikan berkaitan dengan ukuran dan kebersihan luka serta perawatannya. ${ }^{14}$ Berkaitan dengan itu olesan madu mempercepat penyembuhan luka. Madu juga telah digunakan untuk mengurangi bau busuk yang berasal dari luka. ${ }^{15,16}$

Pada penelitian ini, dari 4 konsentrasi yang digunakan untuk proses penyembuhan luka, konsentrasi yang paling efektif adalah konsentrasi tertinggi yaitu pemberian $100 \%$ madu.

\section{SIMPULAN}

Pemberian madu berpengaruh terhadap penurunan TNF $\alpha$ walaupun tidak bermakna secara statistik, dan pemberian madu berpengaruh terhadap penyembuhan panjang dan penyembuhan lebar luka pada tikus galur wistar jantan.

Disarankan untuk penelitian selanjutnya perlu dilakukan pemeriksaan TNF a dalam 2-6 jam setelah dilukai, memakai jenis madu yang lain, dan lebuh memperhatikan efek anti bakteri, anti inflamasi dan anti oksidan pada madu.

\section{UCAPAN TERIMA KASIH}

Penulis mengucapkan terima kasih kepada pembimbing, Kepala Laboratorium Farmasi beserta staf dan Kepala Laboratorium Biomedik beserta staf yang telah membantu dalam pemeliharaan hewan coba dan membantu pemeriksaan sampel.

\section{DAFTAR PUSTAKA}

1. Tarigan, $\mathrm{R}$ dan Pemila U. Moist Wound Healing. New England Journal Medicine. 2007.14(3) : $143-156$

2. Zulfa, Perbandingan Penyembuhan Luka Terbuka Menggunakan Balutan Madu atau Balutan Normal Salin - Povidone lodine. Jurnal Keperawatan Indonesia. 2008 :12 (1) : 34-39

3. Sasaki $M$, Kashima $M$, Ito $T$, Differential regulation of metalloproteinase production, proliferation and chemotaxis of human lung fibroblasts by PDGF, interleukin-1beta and TNF-alpha. Inflamm Mediator. 2000 : (9) : 155160

4. Widodo, A. Budidaya Lebah Madu Sengatan Untungnya Kian Diburu. Yogyakarta.Pustaka Baru Press. $2010: 128-133$

5. Eteraf $T$, Using Of Natural Honey and Tradition Modern in Human Desease a observasion, Iranian Journal of Basic Medical Science.2013 :16(6) : 731- 742

6. Yaghoobi R, Kazerouni A, Kazerouni $O$. Evidence for Clinical use of Honey in Wound Healing as an Anti-Bacterial, Anti-Inflammatory Anti-Oxidant and Anti-Viral Agent:A review. Jundishapur . 2013.8 (3) : $100-104$

7. Tonks AJ, Cooper RA, Jones KP, Blair S, Parton J, Tonks A, 2003. Honey Stimulates Inflammatory Cytokine Production From Monocytes. 2003. Cytokine, 21 (5): 242-247

8. Tonks A, Cooper RA, Price AJ, Molan PC Jones KP. Stimulation Of Tnf-Alpha Release In Monocytes By Honey. 2001.Cytokine.14. (4) : 240-242

9. Gethin, G.T, Cowman, S., and Conroy, R.M. The impact of Manuka honey dressings on the surface $\mathrm{pH}$ of chronic wounds. Int. Wound J. $2008: 5$ (2) : 185-194

10. Khan FR, UIAbadin Z, Rauf N. Honey: nutritional and medicinal value. Int $\mathrm{J}$ ClinPract. 2007 : 61(10): 1705-1707

11. Al-Waili NS, Salom K, Butler G, Al Ghamdi AA. Honey and microbial infections: a review supporting the use of honey for microbial control. J Med Food. 2011: 14 (10) :1079-1096.

12. Molan PC.The Evidence Supporting the use of Honey as a Wound Dressing.Int $J$ Lower Extremity Wounds. $2006: 5$ (1) : 40-54

13. Molan PC.A Brief Review of the use of Honey as a Clinical Dressing.Aust $\mathrm{J}$ Wound Mange. $1998: 6$ (4) :148-158

14. Lund-Nielsen B, Adamsen L, Kolmos HJ, Rorth M, Tolver A, GottrupF. The Effect of Honeycoated andages Compared with silver-coated bandages on Treatment of Malignant Woundsarandomized study. Wound Repair Regen. 2011:19 (6) : 664-670

15. Yapucu Gunes U, Eser I. Effectiveness of a honey dressing for healing pressure ulcers. J 
Wound Ostomy Continence Nurs. $2007: 34$ (2) :184-190

16. Simon A, Traynor K, Santos K, Blaser G, Bode $U$, Molan P. Medical Honey for Wound care-still the 'Latest Resort'? Evid Based Complement Alternat Med. 2009: 6 (2) :165-173 